\title{
Maksym Bonarek
}

Uniwersytet Marii Curie-Skłodowskiej w Lublinie

maksym.bonarek@gmail.com

\section{Zastrzeżenie tajemnicy przedsiębiorstwa jako forma ograniczenia zasady jawności postępowania o udzielenie zamówienia publicznego}

\author{
The Stipulation of Trade Secret as a Form of Limiting the Principle \\ of Transparency in Public Procurement Procedure
}

\section{STRESZCZENIE}

Omówienie właściwości postępowania o udzielenie zamówienia publicznego, w tym materii dotyczącej naczelnych zasad wyznaczających standardy procedury zamówień publicznych, stanowi niezwykle ważny aspekt w kontekście działalności podmiotów publicznych. Przybliżenie istoty wzajemnych relacji pomiędzy zasadą jawności a ograniczeniami w zakresie jej stosowania umożliwia wyznaczenie katalogu przesłanek uzasadniających przyznanie ochrony interesowi przedsiębiorcy. Zarówno wskazanie na potrzebę weryfikacji zasadności zastrzeżenia pod kątem jego skuteczności, jak i wyjaśnienie roli uczestników postępowania dodatkowo przybliża specyfikę postępowania. Artykuł zawiera podstawowe zestawienie informacji stanowiących wyznacznik dla przedsiębiorcy uczestniczącego w postępowaniu o udzielenie zamówienia publicznego.

Słowa kluczowe: tajemnica przedsiębiorstwa; zamówienia publiczne; zasada jawności; przedsiębiorca; interes publiczny; interes indywidualny

\section{WSTĘP}

Zasada jawności informacji publicznej jest jedną z naczelnych zasad wyznaczających standardy działania podmiotów publicznych. Oparcie systemu prawnego na rzeczywistej jawności podejmowanych działań wynika wprost z Konstytucji ${ }^{1}$, której bezpośrednie stosowanie stanowi gwarant przejrzystości także w ramach

1 Konstytucja Rzeczypospolitej Polskiej z dnia 2 kwietnia 1997 r. (Dz.U. z 1997 r., nr 78, poz. 483), art. 54 i 61 . 
realizacji procedury zamówień publicznych. Zapewnienie prawa do informacji, wynikającego de facto z idei partycypacji społeczeństwa w zadaniach wykonywanych przez organy władzy publicznej, pełni rolę narzędzia ograniczającego występowanie nieprawidłowości w sferze zamówień publicznych. Zapewnienie należytej ochrony interesu publicznego, poprzez stworzenie mechanizmu umożliwiającego kontrolę nad omawianą procedurą, nie zawsze będzie bezwzględnie skuteczne - ustawodawca bowiem przewidział określone sytuacje, w których zasada jawności podlega ograniczeniu.

Przepisy ustawy Prawo zamówień publicznych ${ }^{2}$ przyznają zamawiającemu kompetencję ograniczenia dostępu do informacji lub nieujawniania niektórych danych (np. art. 8 ust. 2 i 4 PZP). Przyjęcie takiej konstrukcji wprowadza do systemu wyjątki od zasady jawności, które nie stanowią jednak podstawy wprost do zastosowania zakazu ujawniania konkretnych informacji. Takie uprawnienie przyznaje natomiast przepis art. 8 ust. 3 PZP, który ex lege zakazuje ujawniania danych stanowiących tajemnicę przedsiębiorstwa w rozumieniu przepisów o zwalczaniu nieuczciwej konkurencji ${ }^{3}$. Redakcja przepisu określanego mianem najistotniejszego odstępstwa od zasady jawności dodatkowo wskazuje na fundamentalne znaczenie w kontekście toczącego się postępowania ${ }^{4}$.

Przybliżenie istoty wzajemnych relacji pomiędzy zasadą jawności a zastrzeżeniem poufności informacji w ramach tajemnicy przedsiębiorstwa odgrywa podstawową rolę w kontekście zarówno prawidłowego prowadzenia postępowania, jak i wskazania przesłanek uzasadniających przyznanie ochrony interesowi przedsiębiorcy. Celem niniejszego artykułu jest dokonanie analizy zasady jawności oraz omówienie wpływu klauzuli poufności na procedurę zamówień publicznych.

\section{ZASADA JAWNOŚCI - POJĘCIE ORAZ OGRANICZENIA STOSOWANIA}

Rozpoczęcie rozważań nad przedmiotowym zakresem problematyki niniejszego opracowania wprowadza konieczność wyjaśnienia pojęć kluczowych z punktu widzenia logicznego układu treści pracy. Omówienie właściwości postępowania o udzielenie zamówienia publicznego wymaga przede wszystkim dokonania wykładni przepisu art. 2 pkt 7a PZP, który stanowi, że przez pojęcie postępowania

2 Ustawa z dnia 29 stycznia 2004 r. - Prawo zamówień publicznych (Dz.U. z 2004 r., nr 19, poz. 177 z późn. zm.), dalej jako: PZP.

3 Ustawa z dnia 16 kwietnia 1993 r. o zwalczaniu nieuczciwej konkurencji (Dz.U. z 1993 r., nr 47, poz. 211 z późn. zm.), dalej jako: ZNKU.

4 Skutkiem objęcia oferty, złożonej w postępowaniu o udzielenie zamówienia, klauzulą tajemnicy przedsiębiorstwa, jest związanie tą klauzulą zamawiającego, który działając w charakterze podmiotu zobowiązanego do udzielenia informacji publicznej, nie ma innej możliwości, niż odmówić udostępnienia dokumentów - na podstawie wyroku NSA z dnia 17 lipca 2013 r., I OSK 608/13. 
należy rozumieć postępowania wszczynane w drodze publicznego ogłoszenia o zamówieniu lub przesłania zaproszenia do składania ofert albo przesłania zaproszenia do negocjacji w celu dokonania wyboru oferty wykonawcy, z którym zostanie zawarta umowa w sprawie zamówienia publicznego, lub - w przypadku trybu zamówienia z wolnej ręki - wynegocjowania postanowień takiej umowy.

W systemie prawa krajowego zasada jawności została skodyfikowana w art. 8 ust. 1 PZP. Jawność postępowania jako jedna z naczelnych zasad, na której opiera się procedura zamówień publicznych, stanowi gwarant dostępu do informacji i dokumentów dotyczących postępowania. Poprzez realizację konstytucyjnej zasady jawności działań podmiotów publicznych oraz korelatywny związek z zasadą przejrzystości (art. 7 PZP), jawność wyznacza obowiązek zapewnienia dostępu nie tylko uczestnikom postępowania, ale także wszystkim podmiotom zainteresowanym jego przebiegiem ${ }^{5}$. Przyjęte rozwiązanie zmierza do zapewnienia ochrony interesu publicznego, jak również ochrony interesów konkurentów, w myśl założenia, że pomiędzy interesem publicznym a prawidłowo pojętym interesem prywatnym nie powinny zachodzić kolizje ${ }^{6}$. Na gruncie PZP powyższe standardy urzeczywistniane są m.in. przez':

- zamieszczenie ogłoszenia o zamówieniu w miejscu publicznie dostępnym w siedzibie zamawiającego oraz na stronie internetowej, a także jego publikację w Biuletynie Zamówień Publicznych lub w Dzienniku Urzędowym Unii Europejskiej,

- publikację ogłoszenia o udzieleniu zamówienia,

- udostępnienie Specyfikacji Istotnych Warunków Zamówienia na stronie internetowej,

- zapewnienie jawności otwarcia ofert,

- dokumentowanie postępowania i udostępnienie protokołu z postępowania wraz z załącznikami.

Tak skonstruowany katalog podstawowych zasad służy wprowadzeniu jasnych, klarownych reguł, które zapewnią możliwość zweryfikowania oraz skontrolowania czynności podejmowanych przez zamawiającego ${ }^{8}$.

Dokonanie fundamentalnego podziału w systematyce prawa na „reguły” $\mathrm{i}$,zasady"9 zdaje się uzasadniać koncepcję polskiego ustawodawcy dotyczącą dopuszczalności stosowania ograniczeń od jawności postępowania. Odmienny sposób ich funkcjonowania sugeruje rozbieżności w zakresie prawidłowej interpretacji.

5 Zasada jawności postępowania jest zasadą o charakterze erga omnes. Zob. wyrok KIO z dnia 15 listopada 2012 r., KIO 2370/12.

6 R. Szostak, Zasady prawa zamówień publicznych, Warszawa 2014.

7 Prawo zamówień publicznych. Komentarz, red. M. Jaworska, Warszawa 2018.

8 Zob. wyrok KIO z dnia 23 listopada 2012 r., KIO 2493/12.

9 R.M. Dworkin, The Model of Rules (1967), Faculty Scholarship Series, Paper 3609. 
W oparciu o przyjętą systematykę tylko w przypadkach określonych w ustawie zamawiający ma prawo ograniczyć dostęp do niektórych dokumentów postępowania (art. 8 ust. 2 PZP). Jawność postępowania jest zasadą o pierwszorzędnym znaczeniu na wszystkich etapach postępowania o udzielenie zamówienia, a wszelkie odstępstwa (wyjątki) muszą zostać uzasadnione obiektywnymi okolicznościami faktycznymi i prawnymi ${ }^{10}$. Wśród przepisów ustawy PZP, które ograniczają dostęp do informacji publicznych, należy wskazać przykładowo na ${ }^{11}$ :

- art. 58 ust. 3: w przypadku prowadzenia postępowania w trybie negocjacji, żadna ze stron nie może bez zgody drugiej strony ujawnić informacji technicznych i handlowych związanych z negocjacjami,

- art. 73h ust. 5: w przypadku partnerstwa innowacyjnego z kilkoma partnerami, zamawiający nie ujawnia pozostałym partnerom proponowanych rozwiązań ani innych informacji poufnych udzielanych w ramach partnerstwa innowacyjnego przez jednego z partnerów, bez jego zgody,

- art. 131g ust. 1 pkt 1: w przypadku postępowań prowadzonych w dziedzinach obronności i bezpieczeństwa, zamawiający może zobowiązać wykonawców do zachowania poufnego charakteru informacji przekazywanych im w toku postępowania o udzielenie zamówienia.

Ustawa, wprowadzając generalną zasadę jawności w stosunku do złożonych ofert, czyni także zastrzeżenie o szczególnym znaczeniu dla materii toczącego się postępowania, a zwłaszcza ochrony interesu przedsiębiorcy. Wszak dopuszczenie zastrzeżenia tajemnicy przedsiębiorstwa (klauzula poufności) ma charakter stricte wyjątkowy, stanowi ono niezwykle istotną ingerencję w możliwość zastosowania pierwszeństwa zasady jawności, od której odstępstwa rodzą szereg konsekwencji.

\section{TAJEMNICA PRZEDSIĘBIORSTWA - POUFNOŚĆ INFORMACJI}

Zapewnienie należytej realizacji interesu publicznego nie zawsze pozostaje w relacji zgodności z interesem przedsiębiorcy, którego doniosłość odgrywa niebagatelną rolę $w$ kontekście toczącego się postępowania o udzielenie zamówienia publicznego. Choć zasada jawności bez wątpienia stoi na straży prawidłowego przebiegu procedury, możliwość utajnienia konkretnych danych stanowi skuteczne narzędzie zabezpieczające przedsiębiorcę przed wypływem informacji, których właściwość dotyczy materii zastrzeżonej klauzulą poufności.

Zarówno w doktrynie, jak i orzecznictwie tajemnicę przedsiębiorstwa traktuje się w kategoriach wyjątku od zasady jawności ${ }^{12}$. Przyjęcie takiego stanowiska uza-

\footnotetext{
${ }_{10}$ Zob. wyrok KIO z dnia 15 listopada 2012 r., KIO 2370/12.

${ }_{11}$ Zob. Prawo zamówień publicznych...

${ }_{12}$ Zob. wyrok KIO z dnia 5 maja 2015 r., KIO 851/15.
} 
sadnia usytuowanie przepisu w art. 8 ust. 3 PZP, który pełniąc rolę uzupełniającą, reguluje zasadę jawności w postępowaniu o udzielenie zamówienia publicznego. Zgodnie z brzmieniem przywołanego przepisu, nie ujawnia się informacji stanowiących tajemnicę przedsiębiorstwa w rozumieniu przepisów ustawy z dnia 16 kwietnia 1993 r. o zwalczaniu nieuczciwej konkurencji ${ }^{13}$ pod warunkiem, że wykonawca w odpowiednim terminie zastrzegł, iż nie mogą być one udostępniane. Konieczność dokonania zastrzeżenia konkretnych danych uzasadnia także prawodawstwo unijne poprzez wprowadzenie pojęcia „poufności” oraz wskazanie, iż ,instytucja zamawiająca nie ujawnia informacji przekazanych jej przez wykonawców i oznaczonych przez nich jako poufne, w tym między innymi tajemnic technicznych i handlowych oraz poufnych aspektów ofert" ${ }^{14}$. Możliwość stosowania art. 8 ust. 3 PZP podlega zatem ścisłej wykładni, która wyznacza granice niezbędne do wyeliminowania nadużyć w zakresie zastrzegania określonych informacji tajemnicą przedsiębiorstwa.

Tajemnicę przedsiębiorstwa definiuje art. 11 pkt 4 ZNKU. Zgodnie z definicją ustawodawcy przez tajemnicę przedsiębiorstwa rozumie się nieujawnione do wiadomości publicznej informacje techniczne, technologiczne, organizacyjne przedsiębiorstwa lub inne informacje posiadające wartość gospodarczą, co do których przedsiębiorca podjął niezbędne działania w celu zachowania ich poufności. Tym samym należy uwydatnić trzy warunki, których dopiero kumulatywne spełnienie pozwala uznać określoną informację za tajemnicę przedsiębiorstwa ${ }^{15}$ :

- ma charakter techniczny, technologiczny, organizacyjny przedsiębiorstwa lub posiada wartość gospodarczą,

- nie została ujawniona do wiadomości publicznej,

- podjęto w stosunku do niej niezbędne działania w celu zachowania poufności.

W oparciu o przytoczoną formułę niezbędne staje się, z punktu widzenia odpowiedniej interpretacji, wyróżnienie elementów składowych (przesłanek) zawartych w definicji, takich jak: poufność, brak ujawnienia, zabezpieczenie informacji, wartość gospodarcza. Pierwszą z przesłanek jest poufność informacji, która zostanie spełniona poprzez nieujawnienie informacji do powszechnej wiadomości. Zrozumiałe jest zatem, że konkretna informacja nie może zostać uznana za tajemnicę przedsiębiorstwa, jeżeli jest powszechnie znana lub istnieje możliwość zapoznania się z nią. Kolejna z przesłanek, odnosząca się do zabezpieczenia informacji, jest realizowana przez przedsiębiorcę $\mathrm{w}$ drodze działania mającego na celu zachowanie jej poufności, które mogą mieć charakter zabezpieczeń prawnych i fizycznych. Niezależnie bowiem od rodzaju informacji niezbędne jest, aby przedsiębiorca

13 Dz.U. z 1993 r., nr 153, poz. 153 z późn. zm.

${ }^{14}$ Art. 21 dyrektywy Parlamentu Europejskiego i Rady 2014/24/UE z dnia 26 lutego 2014 r. w sprawie zamówień publicznych.

${ }^{15}$ Zob. wyrok SN z dnia 3 października 2000 r., I CKN 304/00. 
podjął konkretne działania ${ }^{16}$. Ostatnia z przesłanek dotyczy wartości gospodarczej informacji, która będzie podlegała ochronie wyłącznie w przypadku posiadania co najmniej minimalnej wartości gospodarczej ${ }^{17}$. Przyjęcie wartości gospodarczej informacji oraz charakteru technicznego, technologicznego lub organizacyjnego przedsiębiorstwa należy jednak interpretować szeroko. Mogą to być informacje stanowiące know-how przedsiębiorstwa, w tym wiedza techniczna z danej dziedziny, umiejętność wykonania lub wyprodukowania danej rzeczy, patenty obejmujące wynalazki, metody działalności, jak również inne informacje, co do których przedsiębiorca podjął działania w celu zachowania ich poufności ${ }^{18}$. Zapewnienie ochrony tajemnicy przedsiębiorstwa wymaga zatem podjęcia przez przedsiębiorcę działań zmierzających bezpośrednio do wyeliminowania możliwości dostępu osób trzecich do informacji zastrzeżonej tajemnicą (element wolicjonalny przedsiębiorcy $)^{19}$. Z ochrony tajemnicy przedsiębiorstwa nie korzystają natomiast dokumenty (informacje), których obowiązek jawności wynika z odrębnych ustaw:

- na gruncie art. 11 ust. 1 i 4 ZNKU wykluczone jest objęcie tajemnicą przedsiębiorstwa informacji, które można uzyskać w zwykłej i dozwolonej drodze ${ }^{20}$,

- informacje ujawniane przez zamawiającego w czasie otwarcia ofert, tj. nazwa (firma), adres (siedziba) wykonawcy, którego oferta jest otwierana, jak również informacje dotyczące ceny oferty, terminu wykonania zamówienia publicznego, okresu gwarancji, warunków płatności zawartych w ofercie ${ }^{21}$.

Zastrzeżenie klauzul dotyczących wyłączenia jawności znajduje zastosowanie poprzez wykazanie, że określona informacja wymaga nadania jej rygoru poufności ze względu na interes indywidualny przedsiębiorcy. Sytuacja taka może mieć miejsce np.w przypadku zamówień publicznych w przemyśle zbrojeniowym przy składaniu zamówienia na budowę myśliwców nowej generacji.

\section{WARUNKI ZASTRZEŻENIA TAJEMNICY PRZEDSIĘBIORSTWA}

Poza istnieniem obligatoryjnych przesłanek pozwalających zakwalifikować daną informację w kategoriach tajemnicy przedsiębiorstwa ustawodawca przewidział również warunki, jakie musi spełnić wykonawca, aby dokonane przez niego zastrzeżenia były skuteczne. Wykonawca zobowiązany jest:

\footnotetext{
16 Zob. wyrok KIO z dnia 22 listopada 2013 r., KIO 2602/13.

17 A. Michalak, [w:] Ustawa o zwalczaniu konkurencji. Komentarz, red. M. Zdyb, Warszawa 2011.

${ }_{18}$ Ustawa o zwalczaniu nieuczciwej konkurencji. Analiza definicji legalnej w ZNKU. Komentarz, red. J. Szwaja, Warszawa 2016.

19 Zob. wyrok SN z dnia 5 września 2001 r., I CKN 1159/00.

${ }^{20}$ Zob. ibidem.

${ }^{21}$ Art. 86 ust. 4 PZP.
} 
- zastrzec, które informacje podlegają ochronie jako tajemnica przedsiębiorstwa,

- wykazać spełnienie przesłanek określonych w art. 11 ust. 4 ZNKU,

- dokonać zastrzeżenia w odpowiednim terminie.

Podstawowym warunkiem jest fakt dokonania zastrzeżenia przez przedsiębiorcę. Objęcie klauzulą poufności określonych danych nie następuje bowiem z mocy ustawy, konieczne jest złożenie stosownego oświadczenia wskazującego na zakres informacji stanowiących tajemnicę przedsiębiorstwa. W celu zapewnienia kompletności dokumentacji oraz przejrzystości dokonywanego zastrzeżenia niezbędne jest dokładne określenie, jaki „katalog informacji” będzie podlegał wyłączeniu od zasady jawności. To z kolei umożliwi odpowiednia identyfikacja desygnatów wchodzących w zakres znaczeniowy pojęcia. Przyjmuje się, że odstępstwem od zasady jawności może zostać objęty zarówno cały dokument zawierający wyjaśnienia kluczowe dla istoty przedmiotu zamówienia, jak i fragmenty dokumentacji.

Uzasadnieniem podjęcia decyzji o utajnieniu poszczególnych informacji nie mogą być subiektywne względy wykonawcy co do istnienia podstawy zastrzeżenia. Wykazanie interesu przedsiębiorcy musi dotyczyć obiektywnych przesłanek związanych ze zwyczajami i praktyką danej branży lub zawodu ${ }^{22}$. Ponadto objęcie informacji tajemnicą w rozumieniu art. 11 ust. 4 ZNKU wymaga spełnienia czynników o charakterze obiektywnym ${ }^{23}$. Nie jest możliwe zatem zastrzeżenie informacji jako tajemnicy przedsiębiorstwa jedynie w celu uniemożliwienia pozostałym wykonawcom wglądu do dokumentów składanych w ofercie lub wniosku²4.

Dokonanie zastrzeżenia nie byłoby skuteczne bez zachowania właściwego terminu przewidzianego przepisami PZP. W art. 8 ust. 3 PZP został określony termin na zastrzeżenie konkretnych informacji oraz wykazanie zasadności objęcia ich tajemnicą przedsiębiorstwa. $Z$ analizowanego przepisu jednoznacznie wynika, że wykonawca zobowiązany jest zadośćuczynić powyższym wymogom nie później niż w terminie składania ofert lub wniosków o dopuszczenie do udziału w postępowaniu o udzielenie zamówienia publicznego. Choć ustawa w sposób wyraźny wskazuje na termin właściwy do podjęcia określonych czynności, dopuszczalne jest także zastrzeżenie informacji po terminie składania ofert lub wniosków - na dalszym etapie postępowania. Wykonawcy przysługuje wówczas to uprawnienie jedynie poprzez wykazanie konieczności korzystania z ochrony (tj. charakteru informacji). W szczególności możliwe jest zastrzeganie konkretnych danych jednocześnie ze składaniem lub uzupełnianiem dokumentów, składaniem wyjaśnień dotyczących oferty, rażąco niskiej ceny lub kosztu²5.

\footnotetext{
${ }^{22}$ Zob. wyrok SN z dnia 5 września 2001 r., I CKN 1159/00.

${ }^{23}$ Zob. wyrok KIO z dnia 15 listopada 2012 r., KIO 2370/12.

${ }^{24}$ Prawo zamówień publicznych...

25 Ibidem.
} 
Powodzenie zastrzeżenia informacji $\mathrm{w}$ ramach tajemnicy przedsiębiorstwa podyktowane jest szeregiem wymogów, których ciężar spełnienia spoczywa przede wszystkim na wykonawcy zamówienia. Zdaje się zatem, iż zapewnienie ochrony interesu indywidualnego przedsiębiorcy uzasadnia obowiązujący układ odpowiedzialności za prawidłowe dokonanie zastrzeżenia. Dodatkowe obowiązki nałożone na wykonawców, wynikające wprost z PZP, doprowadzą do wzmocnienia pozycji zamawiającego oraz wyeliminowania praktyki zastrzegania przez wykonawców treści ofert i przekazywanych w toku postępowania informacji wyłącznie w celu uniemożliwienia lub utrudnienia pozostałym wykonawcom dostępu do dokumentacji dotyczącej postępowania o udzielenie zamówienia publicznego.

\section{SKUTECZNOŚĆ ZASTRZEŻENIA ZAKAZU UDOSTĘPNIANIA INFORMACJI}

Choć omówiony powyżej układ obowiązków niewątpliwie stawia zamawiającego w roli podmiotu zobligowanego do wykazania zasadności zastrzeżenia, nie bez znaczenia pozostaje pozycja zamawiającego w kontekście dopełnienia jego skuteczności. Zastrzeżenie zakazu udostępniania informacji staje się skuteczne dopiero, gdy zamawiający w wyniku przeprowadzenia stosownej weryfikacji przesądzi o dopuszczalności objęcia określonych informacji tajemnicą przedsiębiorstwa. Nie może jednak w pełni polegać jedynie na oświadczeniu przedsiębiorcy co do faktu spełnienia przesłanek koniecznych z art. 11 ust. 4 ZNKU, powinien bowiem samodzielnie zweryfikować słuszność dokonanego przez wykonawcę zastrzeże$n^{2}{ }^{26}$. W szczególności winna podlegać analizie wartość gospodarcza zastrzeżonych informacji, których doniosłość, z punktu widzenia interesu przedsiębiorcy, przemawia za przyznaniem pierwszeństwa nad zasadą jawności postępowania, ograniczając równocześnie ochronę prawną innych wykonawców. O skuteczności zastrzeżenia przeważa także sposób przeprowadzonej weryfikacji. Co do zasady, możliwości utajnienia podlegają przede wszystkim konkretne informacje, a nie całe zawierające je dokumenty. Zamawiający powinien więc zweryfikować dokument nie tylko pod względem całościowym, ale również poszczególne dane (tj. zwroty, wyliczenia, specyfikacje). Niemniej utajnienie całych dokumentów w sytuacji, gdy zawarte w nich poszczególne informacje nie kwalifikują się do zastrzeżenia (tj. nie spełniają przesłanek koniecznych), będzie możliwe, jeżeli ujawnienie informacji niepodlegającej samodzielnie ochronie mogłoby stanowić

${ }^{26}$ Gdyby jedynym podmiotem decyzyjnym w zakresie stwierdzenia skuteczności dokonanego zastrzeżenia był wykonawca, doprowadziłoby to w efekcie do wykluczenia zamawiającego z roli podmiotu weryfikującego zasadność ograniczenia jawności. Zob. wyrok NSA z dnia 4 sierpnia 2015 r., I OSK 1639/14. 
podstawę do przeprowadzenia logicznego wnioskowania na temat konkurencyjnej oferty objętej tajemnicą ${ }^{27}$.

Rozważając skuteczność zastrzeżenia z powołaniem się na tajemnicę przedsiębiorstwa, należy skupić uwagę również na konsekwencjach braku jego zasadności w kontekście ważności złożonej oferty. Zgodnie z poglądem Sądu Najwyższego „negatywna weryfikacja przez zamawiającego wystąpienia niezbędnej przesłanki ustawowej przesądzającej o skuteczności dokonania zastrzeżenia zakazu udostępniania informacji wywołuje tylko konsekwencje w postaci wyłączenia zakazu ujawniania"28. Wynik negatywnej weryfikacji nie przesądza zatem o niezgodności oferty z ustawą (art. 89 ust. 1 pkt 1 PZP), a przesądza tylko o bezskuteczności dokonanego zastrzeżenia. Następstwem przyjętej konstrukcji będzie ważność oferty, z tym że zamawiający nie będzie związany obowiązkiem utajnienia informacji, które wykonawca objął bezskutecznym zakazem ich udostępniania ${ }^{29}$.

\section{PODSUMOWANIE}

Zasada jawności postępowania o udzielenie zamówienia publicznego stanowi gwarant dostępu obywateli i instytucji do danych sektora finansów publicznych, zaś wynikające z niej prawo do informacji publicznej wypełnia przejrzystość gospodarowania środkami publicznymi. Wprowadzenie odstępstw od zasady jawności, poprzez uprawnienie do jej ograniczenia przez zastrzeżenie tajemnicy przedsiębiorstwa, stabilizuje procesy zachodzące w sektorach gospodarki szczególnie wrażliwych na wypływ informacji. Umożliwienie przedsiębiorcy skutecznego zabezpieczenia własnego interesu przesądza o oparciu procedury zamówień publicznych na właściwościach wolnego rynku, niezwykle konkurencyjnego pod względem oferowanych usług. Bieżący układ sił rynkowych, a zwłaszcza warunki konkurencji przejawiające się we wzmożonej rywalizacji przedsiębiorców, zdaje się tym bardziej uzasadniać przyjętą koncepcję ustawodawcy. Wydaje się wysoce nierozsądne bezwzględne stosowanie zasady jawności postępowania w dziedzinach, które ze swej natury są objęte rygorystycznymi standardami ostrożności przed wyciekiem informacji objętych poufnością. Trudno bowiem kwestionować słuszność dokonanego zastrzeżenia w przypadku danych o wysokim stopniu zaawansowania technicznego, np. z zakresu przemysłu zbrojeniowego czy sektora informatycznego, w których ujawnienie informacji wiązałoby się bezpośrednio ze stratami finansowymi oraz wykorzystaniem strategicznych informacji przez konkurentów. Zachowanie odpowiednich proporcji w ujęciu zapewnienia nale-

\footnotetext{
27 Zob. wyrok KIO z dnia 21 czerwca 2011 r., KIO 1195/11.

${ }^{28}$ Zob. uchwała SN z dnia 21 października 2005 r., III CZP 74/05.

29 Prawo zamówień publicznych...
} 
żytej ochrony (z reguły) przeciwstawnych interesów wymaga kompleksowego zrozumienia zarówno właściwości rynku, jak i oczekiwań zamawiającego. Zasada, wprawdzie niemająca charakteru bezwzględnego, sugeruje jednak wytyczne, na podstawie których podmioty uczestniczące w postępowaniu mogą skutecznie dochodzić praw wynikających z ochrony tajemnicy przedsiębiorstwa. Ustawodawca słusznie oparł procedurę zamówień publicznych na naczelnych zasadach, takich jak zasada jawności postępowania, zaś wprowadzanie form ograniczeń od jej stosowania czyni procedurę znacznie przystępniejszą dla przedsiębiorców.

\section{BIBLIOGRAFIA}

Dworkin R.M., The Model of Rules, Faculty Scholarship Series 1967, Paper 3609.

Dyrektywa Parlamentu Europejskiego i Rady 2014/24/UE z dnia 26 lutego 2014 r. w sprawie zamówień publicznych.

Konstytucja Rzeczypospolitej Polskiej z dnia 2 kwietnia 1997 r. (Dz.U. z 1997 r., nr 78, poz. 483).

Michalak A., [w:] Ustawa o zwalczaniu konkurencji. Komentarz, red. M. Zdyb, Warszawa 2011.

Prawo zamówień publicznych. Komentarz, red. M. Jaworska, Warszawa 2018.

Szostak R., Zasady prawa zamówień publicznych, Warszawa 2014.

Uchwała SN z dnia 21 października 2005 r., III CZP 74/05.

Ustawa o zwalczaniu nieuczciwej konkurencji. Analiza definicji legalnej w ZNKU. Komentarz, red. J. Szwaja, Warszawa 2016.

Ustawa z dnia 16 kwietnia 1993 r. o zwalczaniu nieuczciwej konkurencji (Dz.U. z 1993 r., nr 47, poz. $211 \mathrm{z}$ późn. zm.).

Ustawa z dnia 29 stycznia 2004 r. - Prawo zamówień publicznych (Dz.U. z 2004 r., nr 19, poz. 177 z późn. zm.).

Wyrok KIO z dnia 21 czerwca 2011 r., KIO 1195/11.

Wyrok KIO z dnia 15 listopada 2012 r., KIO 2370/12.

Wyrok KIO z dnia 23 listopada 2012 r., KIO 2493/12.

Wyrok KIO z dnia 22 listopada 2013 r., KIO 2602/13.

Wyrok KIO z dnia 5 maja 2015 r., KIO 851/15.

Wyrok NSA z dnia 17 lipca 2013 r., I OSK 608/13.

Wyrok NSA z dnia 4 sierpnia 2015 r., I OSK 1639/14.

Wyrok SN z dnia 3 października 2000 r., I CKN 304/00.

Wyrok SN z dnia 5 września 2001 r., I CKN 1159/00.

\section{SUMMARY}

Overviewing the peculiarity of the public procurement procedure, including the matter of primate rules designating standards of the procedure itself, plays an important role in the context of public entities' activity. The closer look at the essence of mutual relations between the principle of transparency and its restrictions enables to designate a catalogue of terms that justify the granting of protection for entrepreneur's interest. By characterizing both the need to proper verification of the validity of the limitations over its effectiveness and participants roles in the proceeding, the purpose 
Pobrane z czasopisma Studenckie Zeszyty Naukowe http://szn.umcs.pl Data: 26/04/2023 13:29:25

Zastrzeżenie tajemnicy przedsiębiorstwa jako forma ograniczenia zasady jawności...

of the paper is to explore the specificity of the public procurement procedure. The following article provides the basic summary of the most crucial information constituting determinants for an entrepreneur who participates in the proceeding.

Keywords: trade secret; public procurement procedure; the principle of transparency; entrepreneur; public interest; individual interest 